\title{
DEVELOPMENT OF A LASER PROFILOMETER FOR THE GENERATION OF 3D- MODELS TO MEASURE THE VOLUME OF FERTILIZER APPLIED BY FERTILIZER SOWERS
}

\author{
Antonio Carlos Loureiro Lino ${ }^{1}$, Edson D’Avila ${ }^{2}$, Marcos Valério Gebra da Silva ${ }^{3}$ (D), Inácio Maria dal Fabbro ${ }^{4}$ (D), Denival \\ da Costa Silva $^{5}$ (1D)
}

1 - Agriculture Engineer Ph.D. in Agriculture Engineering Researcher, CEA/IAC. lino@iac.sp.gov.br

2 - Electrical Engineer Ph.D. in Agriculture Engineering, Professor IFSP. davila@ifsp.edu.br

3 - Electrical Engineer Ph.D. in Agriculture Engineering, Professor UNIFAJ. marcosgebra@terra.com.br

4 - Agronomist Ph.D. in Agriculture Engineering, Professor UNICAMP. inacio@agr.unicamp.br

5 - Industrial Automation Technologist, CEA/IAC. costasilvadenival@gmail.com

\section{Keywords:}

Image processing

Laser triangulation

Three-dimensional models

\section{ABSTRACT}

Laser profilometry based on triangulation is a method for measuring depth of points in space that uses a laser beam to scan the object. The image of a laser-line projected onto a surface of an object is captured and treated in image-analysis software, which calculates its profile. The union of a sequence of profiles allows the construction of the 3D-digital models of objects. The objective of this work was to develop a methodology and to build a prototype of a threedimensional scanner based on laser triangulation. A prototype was built, with a gantry structure containing a car on which are a laser diode and a camera. This car is driven by an endless shaft driven by an electric motor with variable speed. When moving the car, the laser module produces a line on the surface of the object that is filmed by a camera fixed at a known angle, obtaining the necessary information to generate the 3D model of the object. Tests were made on regular objects: hubcaps, pyramids and cobblestones and the results showed that the 3D-models produced had the same dimensions. Tests were also made on irregular objects such as soil surface and fruit. The prototype proved to be solid for generating 3D models of objects.

\section{Palavras-chave:}

Processamento de imagem

Triangulação laser

Modelos tridimensionais

\section{DESENVOLVIMENTO DE UM PERFILÔMETRO LASER PARA A GERAÇÃO DE MODELOS 3D VISANDO A MEDIÇÃO DO VOLUME DE FERTILIZANTES APLICADOS POR SEMEADORAS-ADUBADORAS}

\section{RESUMO}

A perfilometria a laser, baseada na triangulação, é um método para a medição de profundidade de pontos no espaço em que se utiliza um feixe de laser para sondar o objeto. A imagem de uma linha laser projetada sobre uma superfície de um objeto é capturada e tratada em software de análise de imagens, que calcula o seu perfil. A união de uma sequência de perfis permite construir os modelos digitais 3D de objetos. O objetivo deste trabalho foi desenvolver uma metodologia e construir um protótipo de um scanner tridimensional baseado em triangulação laser. Foi construído um protótipo, com uma estrutura do tipo pórtico que contendo um carro sobre o qual estão um diodo laser e uma câmera. Este carro é acionado por um eixo semfim movido por um motor elétrico de velocidade variável. Ao deslocar o carro, o módulo laser produz uma linha na superfície do objeto que é filmada por uma câmera fixada à um angulo conhecido, obtendo as informações necessárias para gerar o modelo 3D do objeto. Foram feitos testes em objetos regulares: calotas, pirâmides e paralelepípedos e os resultados mostraram que os modelos 3D produzidos tinham as mesmas dimensões. Também foram feitos testes em objetos irregulares como superfície do solo e frutas. O protótipo mostrou-se robusto para gerar modelos 3D de objetos. 


\section{INTRODUCTION}

One of the factors that most influence crop productivity is soil fertility. In order to maintain or even improve fertility, it is necessary to use fertilizers and correctives, which have an important participation in production costs. As a result, the correct dose and their uniform and efficient distribution are directly related to the profitability of agriculture.

The use of sowing-fertilizer machines is common in the implantation of grain crops in Brazil. These machines apply fertilizers directly to the sowing furrow. For Peche Filho et al. (2012) fertilizer application is one of the most important operations of the crop cycle, and possible failures may result in significant losses. Garcia (2007) mentions that the uniformity of distribution and its proper deposition become continuously important, since fertilizers are responsible for a large part of the total cost of production.

According to Brandt (2010), the fertilizer dispenser is the component of fertilizers that most affects the performance of this type of machine. Also, for Altmann et al. (2010), working inclination, the speed of activation and the type of fertilizer are the factors that most influence the functioning of these mechanisms.

Several methodologies have been used to evaluate the longitudinal distribution of the metering mechanisms of seeder-fertilizers.

In order to measure the flow of fertilizers applied by metering mechanisms, Ferreira et al. (2010) and Reynaldo (2013) used containers for collection in a determined period of time, which were later weighed.

On the other hand, Santos et al. (2014) measured the mass of fertilizer in the laboratory and in the field. The laboratory methodology consisted of measuring the mass of fertilizer deposited in the collecting pots over 5 meters, which were subsequently weighed. In the field methodology, the test was carried out by placing a $25-\mathrm{m}$ gutter equipped with $9 \times 7.5 \mathrm{~cm}$ collecting pots on the central line of the seeder-fertilizer machine. The fertilizer-conducting tube was placed over the collecting-gutter, thus, metering the fertilizer over the collecting pots which were placed over it.

Bica and Souza (2009) developed a mass-flow sensor, consisting of a steel-blade placed under the meter, which undergoes elastic deformation when the fertilizer falls on it. This deformation is measured by an extensometer.

Dos Santos et al. (2016) developed a sensor that is based on the electromagnetic induction principle, in which two field-coils were excited with a signal in order to obtain the flow of fertilizers.

Optical profilometric techniques can be used for the study in several areas of agricultural engineering such as: mechanical behavior, analysis of shape and volume of biological materials, soil roughness, among others.

Among the various techniques, triangulation is probably the oldest method used for measuring the depth of points in space, being probably one of the most common techniques (FERNANDES, 2007, BESI, 1989). A laser beam is usually used to probe the object. It illuminates points on the surface of the object and through a camera placed at a certain angle it locates this point and after processing this information it is possible to determine the distance from the illuminated points. According to the distance of the object's surface, the point appears in different places on the image. This technique is denominated triangulation because a triangle is formed by the laser emitter, the camera and the point generated by the laser on the object's surface,

Storbeck and Daan (2001) used the triangulation technique to recognize the fish species through volume. The system was able to satisfactorily classify approximately $98 \%$ of the fish. Noordam (2007) mentions that the company Green Vision developed a high-speed system for the selection of peppers based on three-dimensional analysis also by laser triangulation.

According to Clark (2000), the working principle of the "Folha de Luz" optical sensor consists of the projection of a plane of light (laser) on the surface to be measured. The intersection of this plane with the surface defines a line that is then captured by a visualization system that according to the triangulation technique is placed at a known distance and inclination in relation to the plane of light. The analysis of the obtained image resulted in the determination of the coordinates of points belonging to the assessed object in a system of known coordinates. A schematic drawing is shown in Figure 1. 


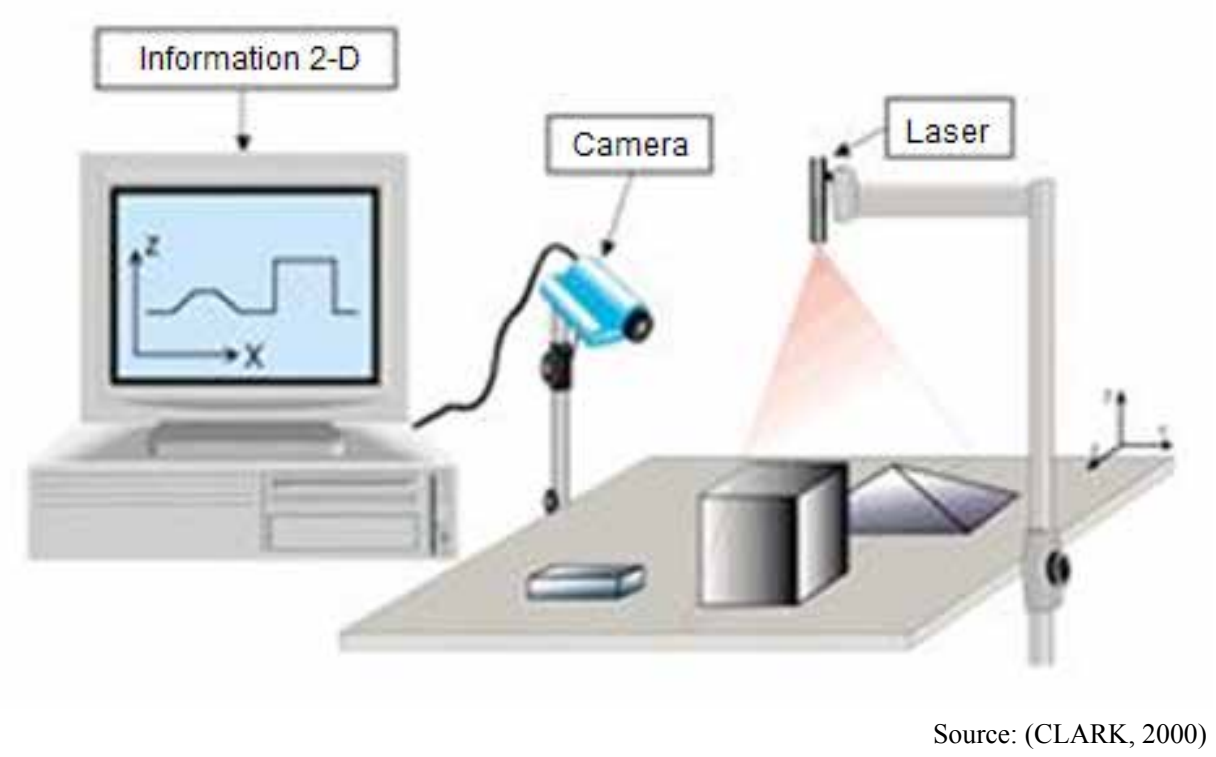

Figure 1. Operating method of "Folha de Luz" optical sensor

The objective of this work was to build a prototype of a three-dimensional scanner based on laser triangulation and to develop a methodology to determine the volume of fertilizers placed in a gutter.

\section{MATERIAL AND METHODS}

The work was carried out at the Image Laboratory of the Engineering and Automation Center of Instituto Agronômico Campinas (IAC), located in Jundiaí, São Paulo State. The experimental arrangement consisted of: Microcomputer with a Core i5-2410M model processor, with 3GB of RAM memory, 2.4G RF wireless camera, coupled to the computer via a USB port and na in-line laser diode $5 \mathrm{~mW}$ and $650 \eta \mathrm{m}$.

It was built a prototype (Figure 2) consisting of a gantry that has an endless shaft, driven by an electric engine of variable speed. This shaft, when rotating, displaces a car with the diode that projects a laser line perpendicular to the surface of the object. In the same car, a camera was adapted, positioned with a $20^{\circ}$ inclination of the laser source, which films the object as the car moves. To capture the video, AMCap v. 9.20 was used.

This methodology was carried out in three stages in which the first part corresponded to the construction of qualitative 3D Digital Models (MDT) with the initial tests, then the system was calibrated and in the third phase, a methodology was developed for the measurement of fertilizer volume.

\section{Development of the methodology for MDT construction}

For the treatment of the images, the ImageJ software was used, so for which it was built a routine that breaks the video into frames, turns each one into shades of gray, where the lighter region corresponds to the laser line, which contains information about the topography of the object under study. Then it corrects the deformations due to the observation angle and creates a new image that contains the topographic information of the object.

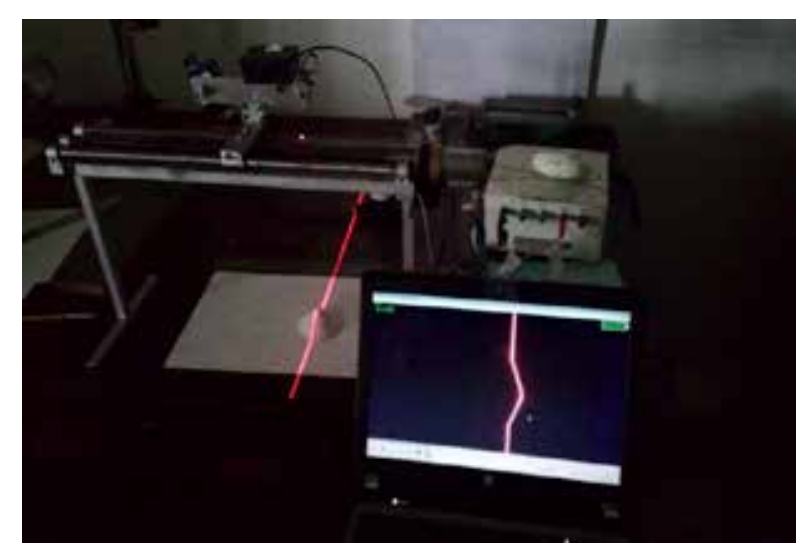

Figure 2. Laser-scanner setup

To test the methodology that creates the MDT of objects, a container with sand was used and the 
word "IAC" was written in a low relief and the scanning was carried out. Next, the same was done for a wax-banana model.

\section{Calibration of the system}

To calibrate the three dimensions of the MDTs obtained by the system and to test the accuracy of the measurements, seven rubber cubes were used, whose dimensions and volumes are shown in Table 1 . Their volumes were calculated using the equation $V=S^{3}$, where $V$ is the volume and $S$ is the side of the cube. These cubes were scanned and their respective MTs were built.

The dimensions of the smallest cube were used to correct the $X, Y$ and $Z$ coordinates by creating the correction factors for the coordinates of the MDTs. The $X$ coordinate corresponds to the displacement of the laser/camera system, in which the number of photos required to cover a known distance, giving a photo/mm ratio. The $Y$ coordinate is given by the number of pixels corresponding to the width of the object of a known width, giving a pixel $/ \mathrm{mm}$ ratio. The $Z$ coordinate is given by the displacement of the laser line projected on the plane and projected on an object of known height, giving a pixel / $\mathrm{mm}$ ratio.

Table 1. Dimension and volume of the cubes

\begin{tabular}{ccc}
\hline Cube & Side $(\mathrm{mm})$ & Volume $\left(\mathrm{cm}^{3}\right)$ \\
\hline 1 & 30.10 & 27.27 \\
2 & 35.90 & 46.27 \\
3 & 40.10 & 64.48 \\
4 & 44.00 & 85.18 \\
5 & 50.10 & 125.75 \\
6 & 60.10 & 217.08 \\
7 & 65.15 & 276.53 \\
\hline
\end{tabular}

After calibration, the volumes obtained by the laser scanner were compared with the calculated volumes and using the Coefficient of Determination $\left(\mathrm{R}^{2}\right)$. This is a measure of adjustment of the volumes obtained by the laser scanner in relation to the calculated values. The higher the $\mathrm{R}^{2}$, the greater the correlation between the measured and the calculated volume.

\section{Methodology for the fertilizer volume quantification}

In the development of the methodology for measuring the fertilizer volume, 4-14-8 granulated were used, with a density of $1.14 \mathrm{~g} / \mathrm{cm}^{3}$. It was deposited in a 50x50x172-mm plastic angle brackets, with a downward apex, forming a "V" channel. Scans were made with the empty gutter and with five volumes of fertilizers deposited on it, 10, 20, 30, 40 and $50 \mathrm{ml}$, measured through a $0.5-\mathrm{ml}$ precision graduated cylinder and weighed on a scale, Marte brand, model AS5500C, with an accuracy of one hundredth of a gram, as shown in Figure 3.

Through the developed routine, six images were generated, where $\mathrm{I}_{0}$, which corresponds to the empty gutter and $\mathrm{I}_{10}, \mathrm{I}_{20}, \mathrm{I}_{30}, \mathrm{I}_{40}$ and $\mathrm{I}_{50}$ to the gutter with the respective volumes of deposited fertilizers. These images in shades of gray, contain the topographic information of the empty gutters and with fertilizers, that is, they constitute their MDTs. The light areas inside them correspond to the regions with the highest elevation and the dark areas are those with the lowest elevation.

Each of the images (MDTs) of the gutter with fertilizers were subtracted from the image of the empty gutter, resulting in the images $\mathrm{F}_{10}, \mathrm{~F}_{20}, \mathrm{~F}_{30}$, $\mathrm{F}_{40}$ and $\mathrm{F}_{50}$, which show the respective amounts of

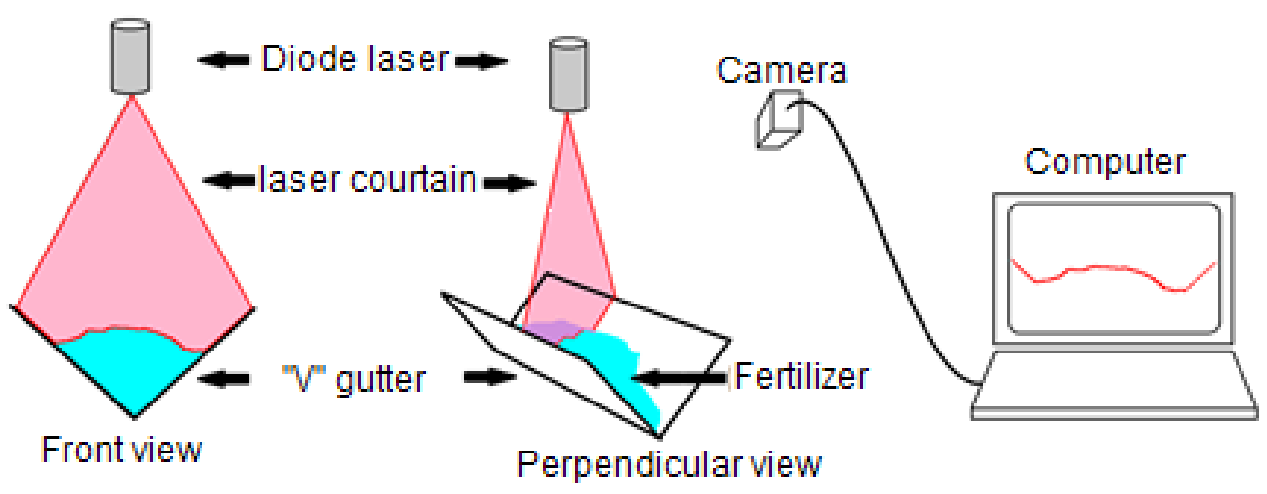

Figure 3. Laser-scanner Setup 
fertilizers contained in the gutters. After, they were filtered to eliminate any artifacts that could cause any error on the measurements.

For the calculation of the volume (pixels ${ }^{3}$ ), the average value of the pixels of the images was determined and multiplied by their number of pixels.

In order to verify the effectiveness of the system, the volume was correlated to the mass of the fertilizer deposited in the gutter and then calculated.

\section{RESULTS AND DISCUSSION}

\section{Development of the methodology}

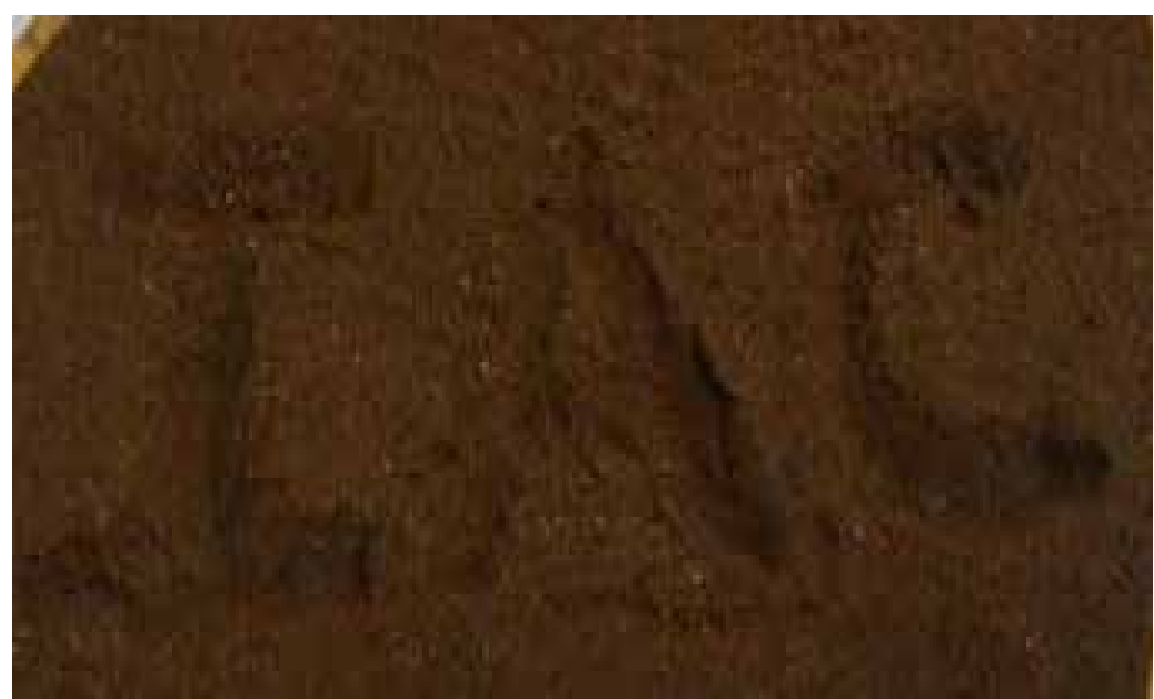

Figure 4. IAC word written in low relief

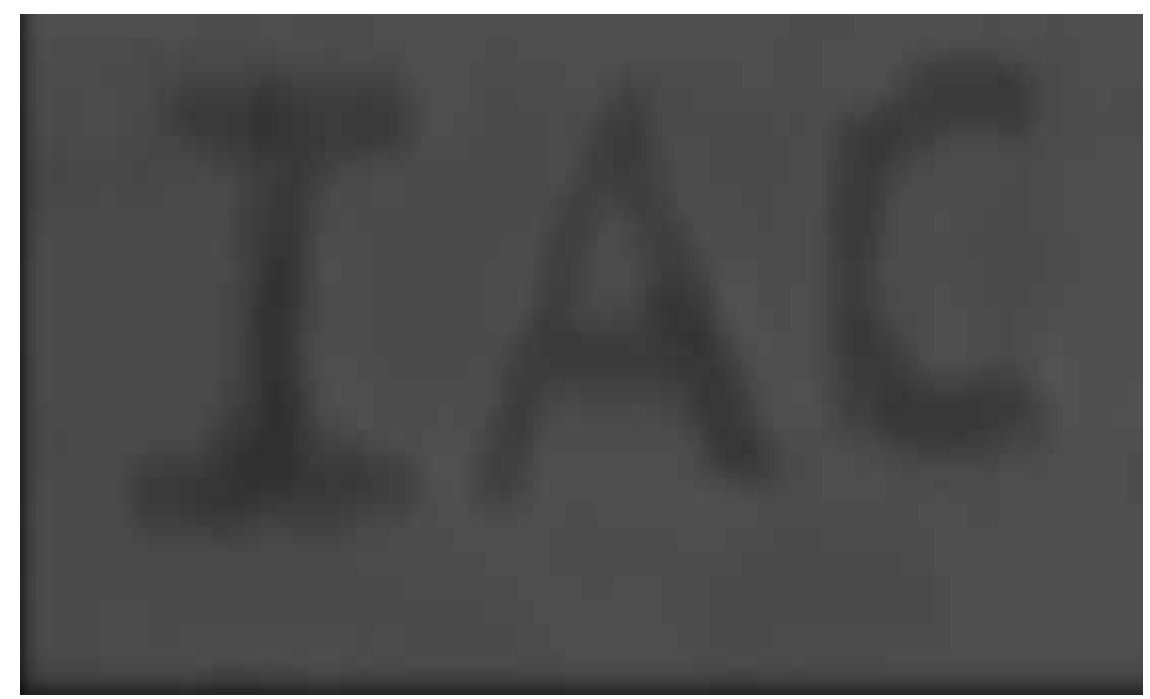

Figure 5. Surface digitalized in shades of gray 


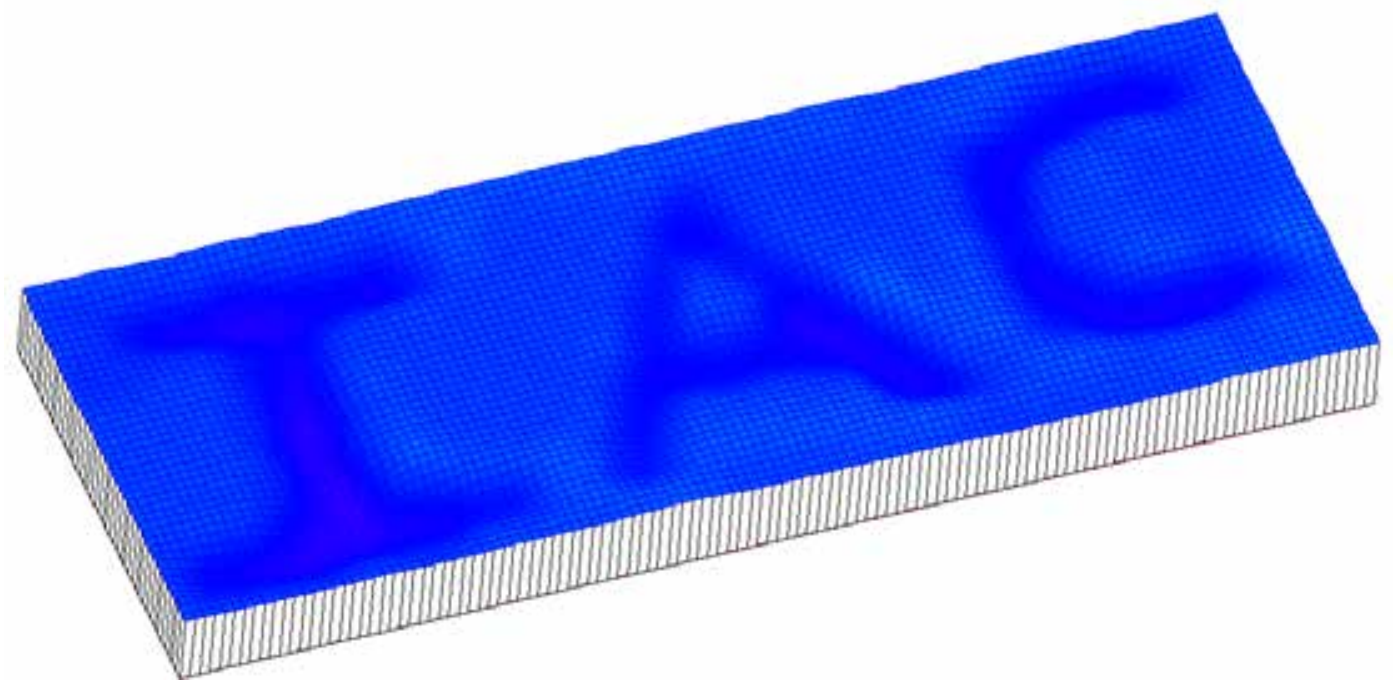

Figure 6. Representation of the wireframe earth's surface
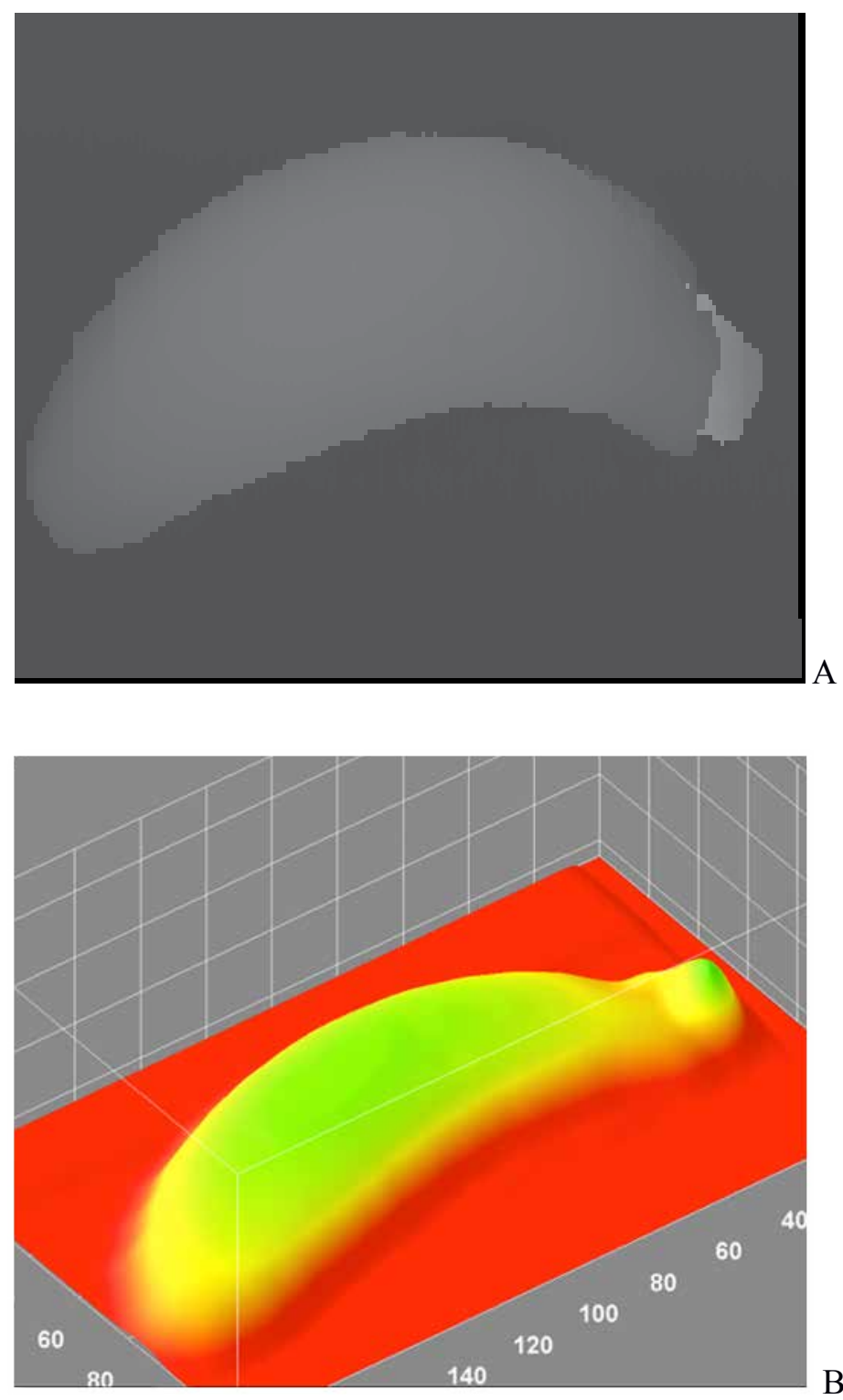

Figure 7. Representation of the banana model topography in shades of gray (A) and in false color (B) 
The system was able to build the qualitative MDTs of the objects.

\section{System calibration}

The results below show the process to calibrate the system (laser scanner) by transforming qualitative MDTs into quantitative ones.

Figure 8 shows the MDT of the cube in false colors, which served to calibrate the system. Figure 9 shows the correlation between the volumes of the cubes calculated by means of the equation and those obtained by the laser scanner. As it can be seen, $\mathrm{R}^{2}$ was 0.9999 , which shows a very high correlation between the volumes, therefore revealing the high accuracy of the laser scanner.

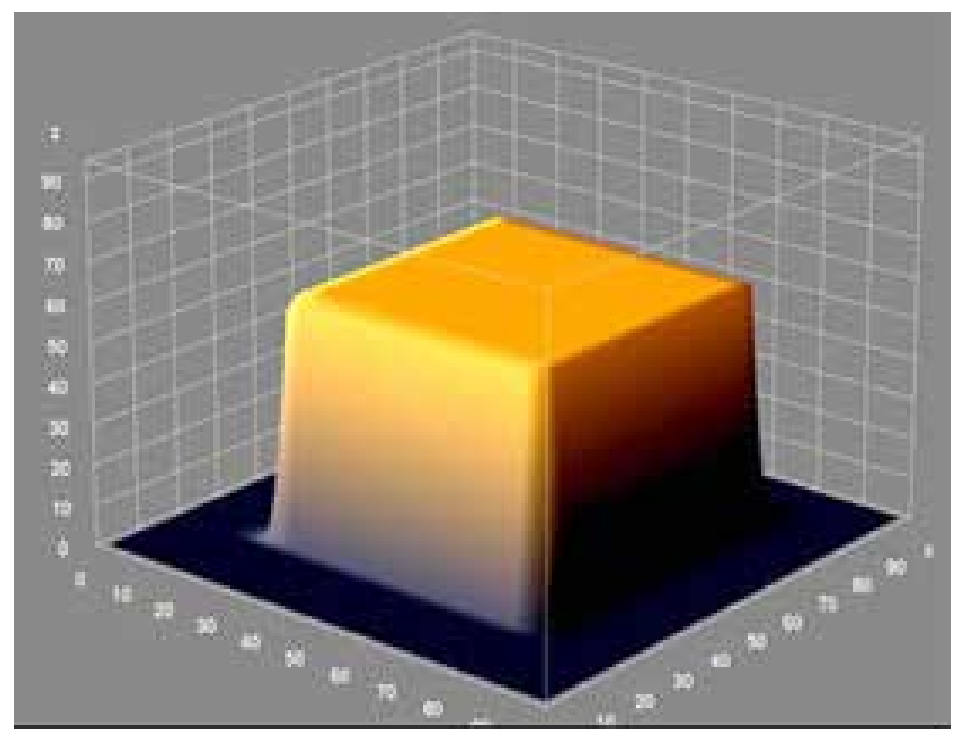

Figure 8. MDT of the cube, in false colors

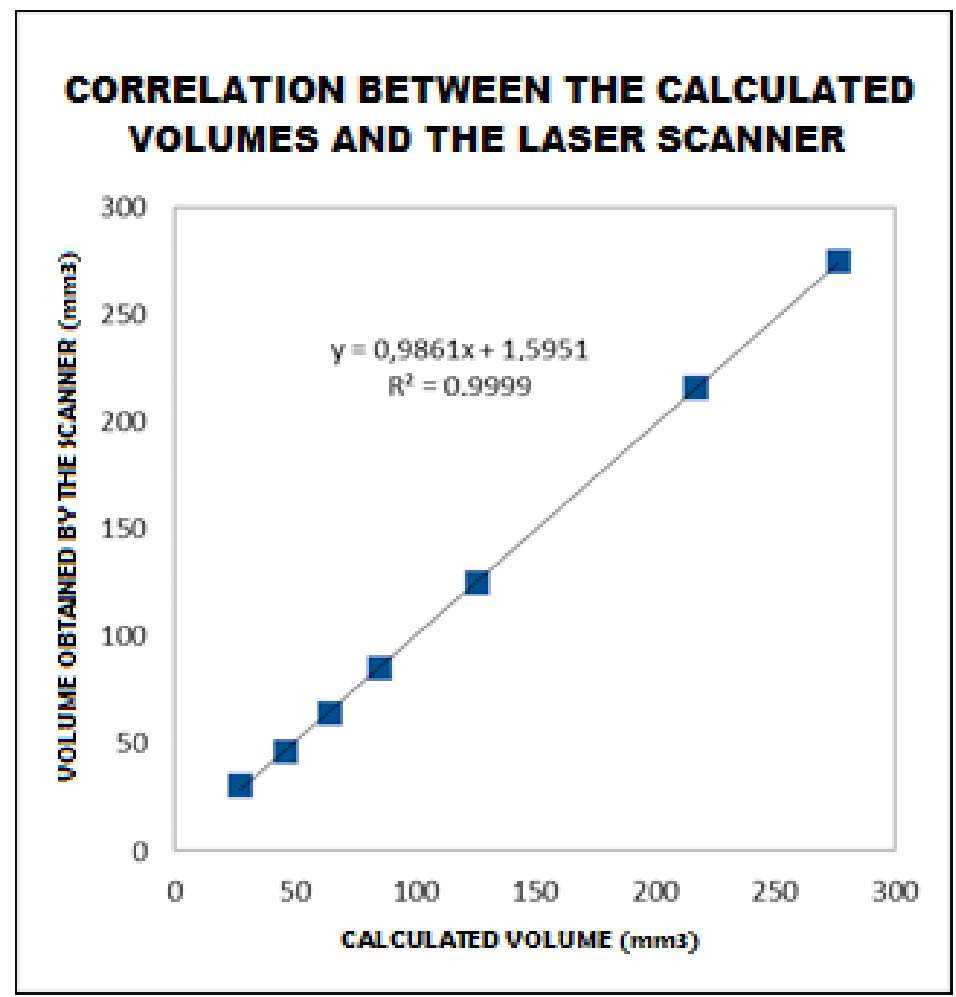

Figure 9. It shows the MDT of the cube, in false colors 
DEVELOPMENT OF A LASER PROFILOMETER FOR THE GENERATION OF 3D- MODELS TO MEASURE THE...

Methodology for quantification of the fertilizer volume

The data below show the results from using the methodology to measure the volume of fertilizers placed in a gutter.

Figure 10A shows the MDT resulting from the empty gutter in shades of gray, where the dark regions show the lowest dimensions (vertex) and the light ones show the upper edges. Figure 10B shows the 3D plot of the same MDT.
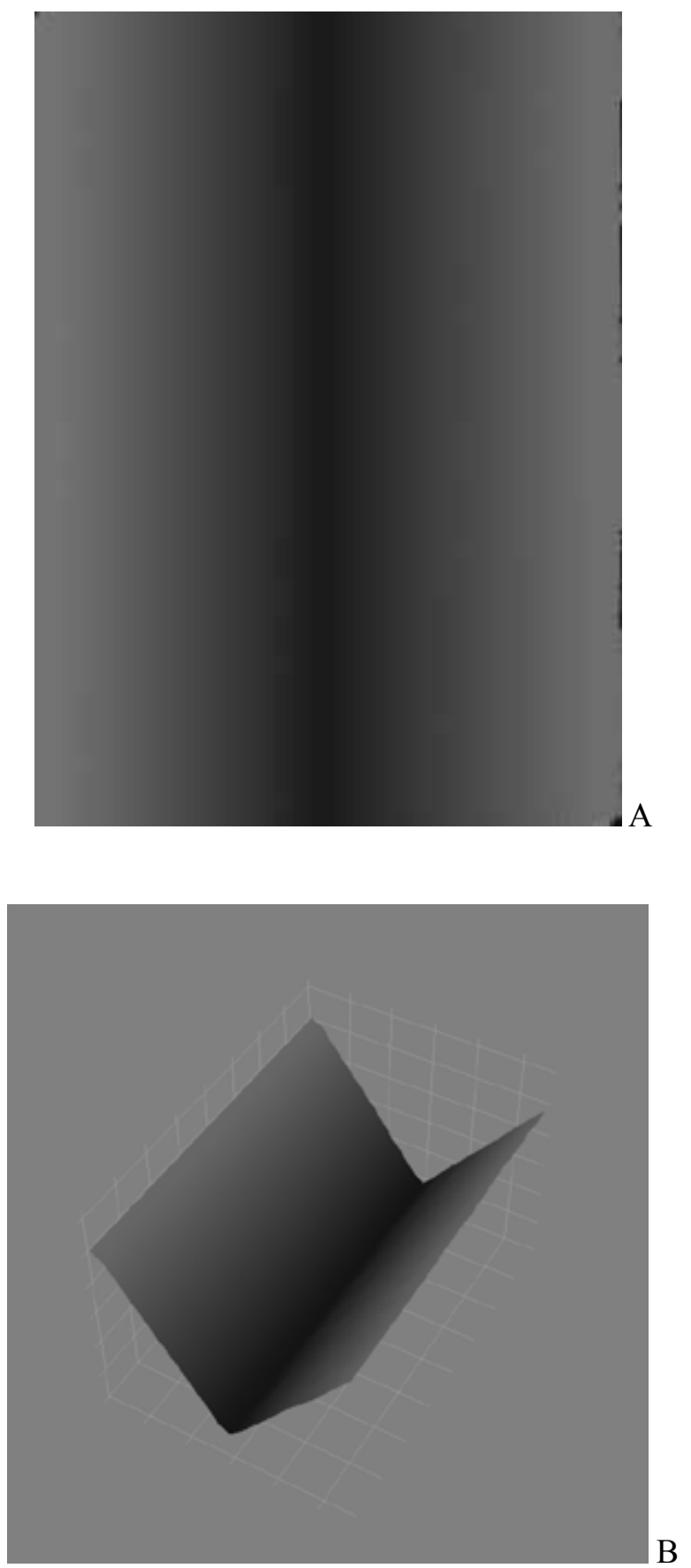

Figure 10. MDT of the empty gutter
Figure 11 A shows the MDT of the gutter with $50 \mathrm{ml}$ of fertilizers, in shades of gray, where the dark regions show the lowest elevations (vertex) and the light ones, the upper edges. Figure $11 \mathrm{~B}$ shows 3D plot of the MDT.
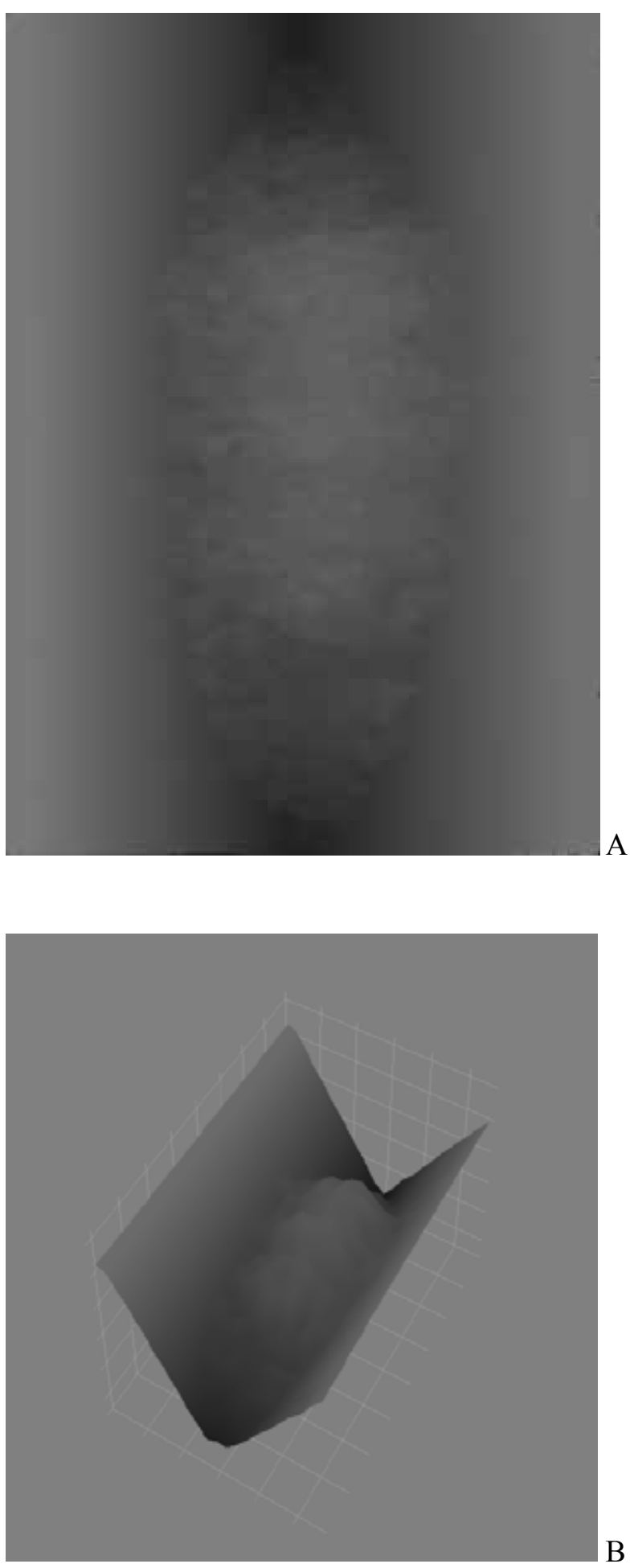

Figure 11. MDT of the gutter with $50 \mathrm{ml}$ of fertilizer 
Figure $12 \mathrm{~A}$ shows the MDT resulting from the subtraction of the gutter with $50 \mathrm{ml}$ of fertilizers by the empty gutter, in shades of gray, where the dark regions show the lowest elevations (vertex) and the light ones show the upper edges. Figure 12 B shows 3D plot of the MDT with false colors.

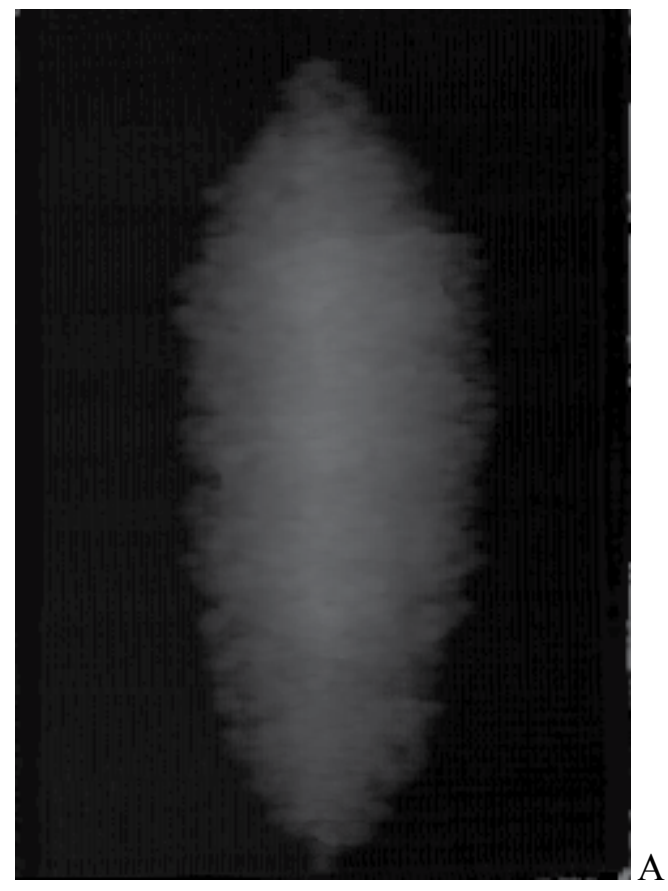

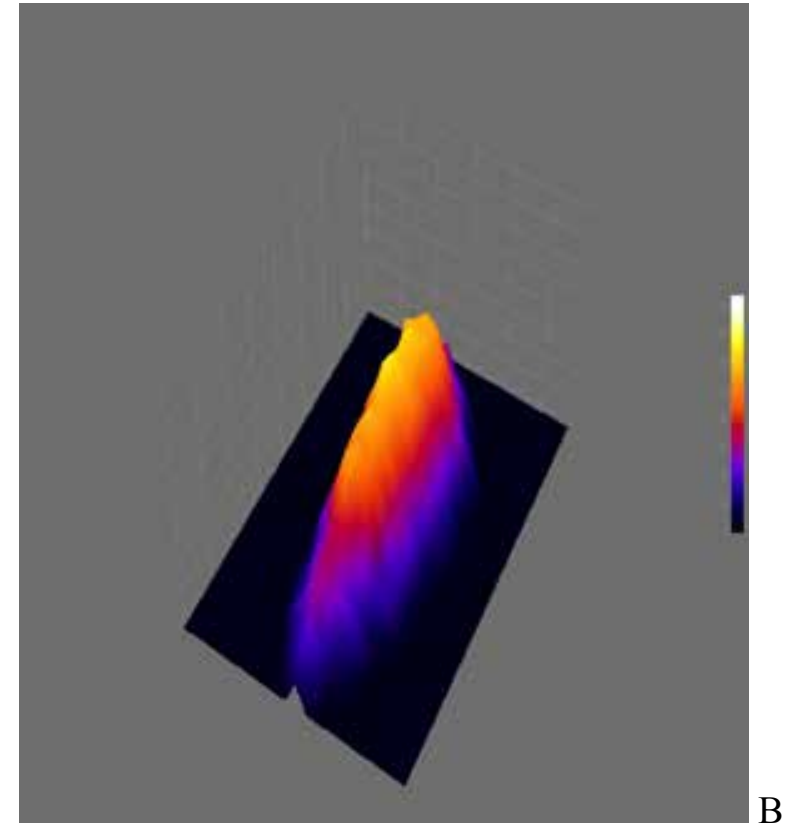

Figure 12. MDT only of the fertilizer

Figure 13 shows the correlation between the calculated volume and the deposited volume of fertilizer with an $\mathrm{R}^{2}$ of 0.9941 . Thus, it shows that the methodology was able to quantify the volume of fertilizer with a high degree of accuracy.

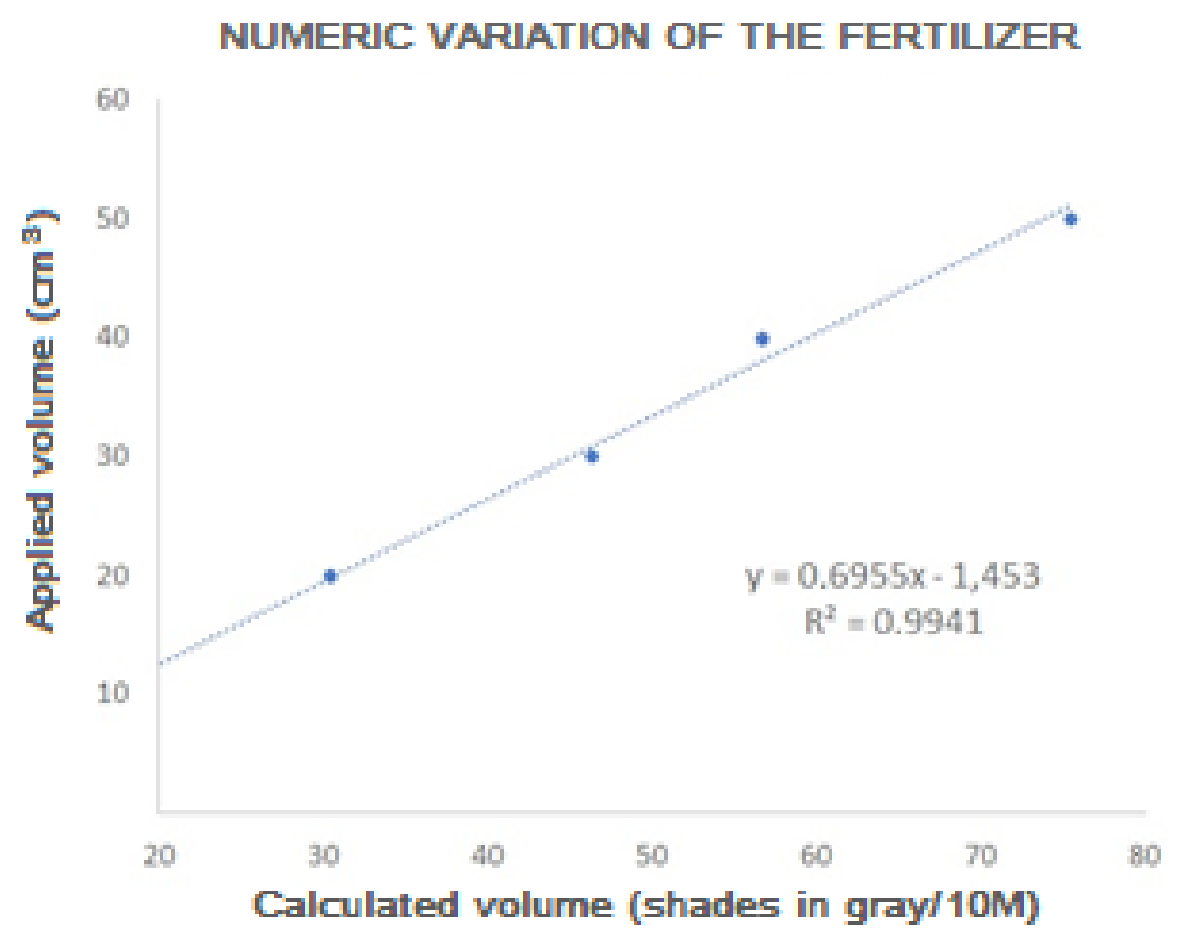

Figure 13. Correlation between the deposited and calculate volume of fertilizer 


\section{CONCLUSIONS}

- The laser-triangulation based 3D scanner was able to digitize the topographic contours of various types of objects, including ground surface, objects with regular and irregular shapes. Also, it was able to calculate the volume of fertilizer deposited in the gutter.

- These initial studies show that the lasertriangulation based 3D scanner has the potential to evaluate fertilizer application by fertilizer-sowers.

- The studies should continue for the development of the technique

\section{ACKNOWLEDGEMENTS}

To FAPESP for the institutional and financial support.

\section{REFERENCES}

ALTMANN, A. S.; BONOTTO, G. J.; BEDIN, P. R.; HENDRIGO, A. T.; CARPES, D. P.; DIAS, V. O.; MONTEMEZZO J.; ALONÇO, A. dos S. Metodologia para avaliação dos mecanismos dosadores de fertilizantes em semeadorasadubadoras. in: XIV Simpósio de Ensino, Pesquisa e Extensão. 10 a 12 de novembro de 2010. Centro Universitário Franciscano.

BESL, P. J. Active optical image sensors. In: SANZ, Jorge L. C. (Ed.). Advances in machine vision. New York: Springer-Verlag, p. 1-63, 1989.

BICA, M. R. R; SOUSA, E. A. C. Medição de vazão mássica para adúbos sólidos em sistemas de adubação a taxas variáveis. In: Seminário da Pós-Graduação em Engenharia Mecânica, 3, 2009. Bauru. Anais... Bauru: UNESP, 2009. Disponível em: $\quad<$ http://www2.feb.unesp.br/pos/seminario/ IIISeminario/anais.php>. Acesso em: 01 out. 2015

BRANDT, M. A. Projeto conceitual de um dosador de fertilizante granulado. $67 \mathrm{f}$. Trabalho de conclusão de curso de Engenharia Mecânica. Universidade Regional do Noroeste do Estado do Rio Grande do Sul, Panambí, 2010.
CLARK, J. - "Implementing Non-Contact Digitisation Techniques Within the Mechanical Design Process", Sensor Review, v. 20, n.3, p. 195-201, 2000.

DOS SANTOS, F. V.; DE OLIVEIRA, F. H. M.; GENTILIN, F. A., DA RIVA, P. B. Medidor de vazão para fertilizantes sólidos por meio de indução eletromagnética através de bobinas. VIII Mostra Interna de Trabalhos de Iniciação Científica, I Mostra Interna de Trabalhos de Iniciação Tecnológica e Inovação. In: Anais eletrônico da ...Maringá, UNICESUMAR, 2016.

FERNANDES; L. A. F. Estudo de Métodos para Extração de Formas e Realização de Medidas a Partir de Imagens, 2007. <http://www.inf.ufrgs. br/ laffernandes/fernandes_TI_1159.pdf $>.10 \mathrm{de}$ abril de 2011.

FERREIRA, M. F. P.; DIAS, V. DE O.; OLIVEIRA, A.; ALONÇO, A. DOS S.; BAUMHARDT, U. B. Uniformidade de vazão de fertilizantes por dosadores helicoidais em função do nivelamento longitudinal. Engenharia na Agricultura, Viçosa, v.18 n.4, p.297-304, 2010.

GARCIA, A. P. Desenvolvimento de um sistema de controle eletromecânico para dosador de fertilizantes. 100 f. Dissertação de Mestrado, Faculdade de Engenharia Agrícola, UNICAMP, Campinas, 2007.

NOORDAM, J.C. Innovative Applications in the Agro and Food industry, 2007. http://greenvision. wur.nl/. 20 de maio de 2007.

PECHE FILHO, A.; CASTIONE, G.; STORINO, M. Avaliação da qualidade de distribuição reduzida de fertilizantes para milho. In: $29^{\circ}$ CONGRESSO NACIONAL DE MILHO E SORGO. Águas de Lindóia, SP. ANAIS, Águas de Lindóia, SP: [s.n.], 2012.

REYNALDO, E. F. Avaliação de mecanismos dosadores de fertilizantes sólidos tipo helicoidais em diferentes níveis de nivelamento longitudinal e transversal. $81 \mathrm{f}$. Tese de Doutorado Universidade Estadual Paulista "Júlio de Mesquita 
Filho Faculdade de Ciências Agronômicas Engenharia Agrícola-CONBEA 2014.

(Campus de Botucatu), Botucatu, 2013.

SANTOS, C. C. dos; ROSA, D. P. da; PAGNUSSAT1, L.; PESINI, F. Metodologia de avaliação de distribuidores de fertilizantes helicoidais. In: XLII Congresso Brasileiro de
STORBECK, Frank; DAAN, Berent. Fish species recognition using computer vision and a neural network. Fisheries Research, v.51, p. 11-15, 2001. 